\title{
Transformational Leadership Potential At A University Of Technology
}

Tessie H H Herbst, Tshwane University of Technology, South Africa

Ajay K Garg, Tshwane University of Technology Business School, Pretoria, South Africa

\begin{abstract}
In South Africa as elsewhere in the world, higher education institutions have been criticised for a lack of transformation. This apparent lack of transformation called into question the capability of the leaders within these institutions to effectively lead change and transform the higher education institutional landscape. The aim of this study was to explore the transformational leadership competency potential amongst managers in a university of technology in South Africa. The measures of potential used are eight competency factors known as the 'Great Eight' (Bartram, 2005) derived from Occupational Personality Questionnaire (OPQ32) scale scores. The OPQ32r was administered to 111 managers within a university of technology. The majority of respondents had a balanced mix of styles between a transformational and transactional focus. These leaders not only exhibit less transformational competencies but also an insufficient strong transactional focus. These findings have severe implications for the transformation of higher education institutions in South Africa.
\end{abstract}

Keywords: Transformational Leadership; Occupational Personality Questionnaire (OPQ); Higher Education; Personality

\section{INTRODUCTION}

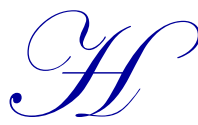

igher education institutions (HEIs) world-wide are faced with a decrease in public funding, while at the same time it is required of them to invest in organisational transformation processes in order to stay relevant in an increasingly competitive market (Bendermacher, Egbrink, Wolfhagen \& Dolmans, 2016). In the same line, HEIs in South Africa (SA) are confronted with major transformation challenges that require exceptional leadership (Herbst \& Conradie 2011; Mader, Scott \& Razak, 2013; Ngcamu, 2015/2016; Seale \& Cross, 2016; Van Ameijde, Nelson, Billsberry \& Meurs, 2009). To address these transformation challenges, the South African government initiated the transformation of the HE landscape agenda with the following aims: to address the inequalities of the past apartheid system; to meet the current demands; and to respond to the new and emerging opportunities and realities in the higher education (HE) sector (Chipunza \& Gwarinda, 2010). These transformation challenges have profound implications for the management and leadership behaviour of managers within universities (Seale \& Cross, 2016), since they are the central 'drivers' of these change and transformation processes (Bendermacher, et al., 2016).

There has recently been a growing interest in the capacity of leaders themselves to effectively address the challenges in the sector (Black, 2015). As stated by Mader et al. (2013: 273) 'addressing these challenges consistently and effectively will not just happen but must be led, and deftly.' Drew (2010) concurs and states that it has never been more critical for leaders in educational environments such as universities, to be able to engage constructively with others to achieve change. In the same line, Ngcamu (2015) is of the opinion that the highly politicized HEIs in South Africa need leaders with excellent personal and interpersonal as well as intellectual capabilities who are able to act as leaders of change and transformation (Potgieter \& Coetzee, 2010). Sirat, Ahmad and Azman (2012) as well as Shahmandi, Silong, Ismail, Samah and Othman (2011) concur and identify the need for university leaders who are not only credible scholars but also progressive visionary and inspirational leaders. However, Ngcamba (2016) states that the rapid universal higher education transformation has left South African universities with untransformed management practices and inadequate capable leadership to meet the new standards. Macupe (2012) concurs and states that the management and leadership of institutions need considerable attention. In 2012 and 2013 alone, five 
public universities were placed under administration for reasons of maladministration, corruption and financial crises (CHE, 2016); providing evidence that the leadership crisis in society broadly is gradually beginning to overwhelm public universities (Mabelebele, 2013). The question is whether the leaders of HEIs are prepared to effectively deal with change of this magnitude and if they have the required leadership potential to demonstrate effective transformational leadership behaviours.

There are not many studies dealing with leadership behaviour in HEIs in South Africa and these studies are inconclusive. For example According to Vinger and Cilliers (2006) the level of transformational leadership amongst leaders in HEIs in SA is relatively high, while Ngcamu (2015) holds an opposing view and states HEIs in South Africa are currently being led 'by individuals who lack transformational capabilities' (p. 209) which directly impede the transformation agenda.

Against the above background the question arises whether HEIs have the transformational leadership capacity to drive the reform and transformation needed in the sector. Exploring this issue will result not only in the successful implementation of future HE transformation goals, but also the fostering of leadership capacity to drive the envisaged changes in the sector.

The aim of this study was to establish whether managers within a university of technology in South Africa, have the potential to demonstrate the transformational leadership competencies that leaders, as agents of change, employ to effect lasting change and transformation in their organisations.

\section{LITERATURE REVIEW}

\section{Transformational Leadership}

Puccio, Mance and Murdoch (2011) describe leadership as a process that is ultimately concerned with inspiring change. As the magnitude and frequency of change increase, so does the importance of leadership and organisational culture (Bartram \& Inceoglu, 2011). Various studies confirm that effective leadership in HE have a positive impact on organisational effectiveness (Lim \& Cromartie, 2001); quality of student learning processes and outcomes (Martin, Trigwell, Prosser and Ramsden, 2003); and service quality in universities that lead to greater competitiveness and long-term sustainability (Evans, 2011; Garwe, 2014).

One leadership model that seems promising in terms of dealing with the constant and ongoing transformation challenges that HEIs in South Africa are faced with is transformational leadership which was introduced by Burns (1978) and later revised by Bass (1985). Burns suggested that leadership could be demonstrated in two distinct forms, transformational or transactional leadership, which in his opinion were the opposites of each other. Transactional leaders have an exchange relationship with their followers. This exchange need not be money or material; it can be, psychological or political (e.g., monetary rewards for productivity, appreciation for loyalty, or benefits for votes). However, the relationship between leader and follower lasts only as long as the exchange and no deeper relationship between leader and follower is formed. In short, transactional leaders focus on the efficient operation of the status quo, as defined by the institution (Bass, 1985). However, to effect change and transform an organisation, Burns argued, another kind of leadership, namely transformational leadership is required. Bass (1985) disagrees from Burns stating that transactional and transformational leadership are not at opposite sides on a continuum but two distinct dimensions of leadership. He argues that a leader can simultaneously be both transactional and transformational but to varying degrees. Furthermore, also, in opposition to Burns, who maintained that leaders should strive for transformational leadership only, Bass (1978) argued that effective leaders use a combination of these two styles and should be both transactional and transformational (Yukl, 1999, Howell \& Avolio, 1993). This is confirmed in research by Judge and Piccolo (2004) who concluded that both leadership styles each has a unique contribution in predicting specific leadership outcomes. Their findings also concluded that transformational leadership was strongly correlated with transactional (contingent reward) leadership, which upholds the view that in practice both are required depending on the context. In higher education, both these theories have been extensively applied and researched and continue to promote interest (Middlehurst, 2012). 
Various authors state that transformational leadership becomes essential for the development of higher education (Bush, 2007; Middlehurst, Goreham \& Woodfield, 2009; Ngcamu, 2015). Rashed and Daud (2013) found that the quality of transformational leadership within a university was significantly related to collective organisational commitment of academic staff. Transformational leadership and participative decision making also have a significant positive impact on job satisfaction of university leturers (Pihie, Sadeghi \& Elias, 2011; Zulfqar, Devos, Shahzad \& Valke, 2015). Furthermore, research has confirmed the link between transformational leadership behaviours and sought after organisational outcomes such as successful transformation (Vinger \& Cilliers, 2006); higher team performance and trust in leadership (Chou, Lin, Chang, \& Chuang, 2013), employees' emotional commitment to organisations (e.g., Barling, Slater \& Kelloway, 2000, Korek, Felfe, \& Zaepernick-Rothe, 2010); self-efficacy (e.g., Salanova, Lorente, Chambel, \& Martinez, 2011); identification with the organisation (e.g., Kark, Shamir, \& Chen, 2003; Wang \& Howell, 2012); as well as empowerment (e.g., Barroso Castro, Villegas Periñan, \& Casillas Bueno, 2008; Gumusluoglu \& Ilsev, 2009).

Anderson and Johnson (2006) and Bolden, Petrov and Gosling (2008) acknowledge that transformational leadership is highly appropriate for the HE sector for the reason that it focus on collective accountability. Black (2015) concurs and states that the traditional style of leadership which involves the close supervision of tasks, is likely to be less effective for professionals like university staff. When managing academic colleagues, this command-and-control style of leadership is especially inappropriate and counterproductive (Goffee \& Jones, 2009). Given the current context of the pressure for change and transformation in HEIs, leaders who act as transformational leaders during the change process will encourgage followers to demonstrate risk-taking behaviours and mobilise the necessary resources towards followers in an attempt to generate the desired level of effort in order to be successful (Chipunza \& Gwarinda, 2010). Furthermore, as stated by Jarvis (2013) 'universities have become like corporations, and are forced to rethink their mission, or their function, in this changing society' (p. 2). In this context, The South African Government is also expecting from HEIs to adapt and transform to business models. As a result, academic leaders are expected to perform in a more corporate way (Loomes, 2014).

\section{Personality and Leadership}

Personality is part of the individual dispositions that underlie or are pre-requisites for leadership behaviours (Bartram, 2009, Colbert, Judge, Choi \& Wang, 2012; Hogan, 2006; Hogan \& Judge, 2013; Judge, Bono, Ilies, \& Gerhardt, 2002). These personality dispositions or traits affect how we habitually think, feel, and act (Saucier \& Goldberg, 2003). Personality, has also been shown to be a predictor of who will emerge as a leader and who will be an effective leader (Judge \& Bono, 2000). As a group, the Big Five personality traits not only predicted leadership emergence $(\mathrm{R}=.53)$ but also leadership effectiveness $(\mathrm{R}=.39)$ (Judge, et al., 2002). This is because personality shapes the specific leadership behaviours exhibited by leaders (Hogan, 2006). In this regard Hogan and Benson (2009) argue that 'leadership is a function of personality, who people are determines how they will lead' (p. 12). Furthermore, if leadership is characterised as process of interpersonal influence (either person to person or via the media) the personality of the individual leader should be a key factor in determining effective, or ineffective influence. Therefore, it is relatively simple to think of having too little or too much of a specific personality trait (Benson \& Campbell, 2007). With regard to transformational leadership, evidence has been found that at the individual level, personalityespecially extraversion (Bono \& Judge, 2004; Do \& Minbashian, 2014), emotional stability, openness to experience, and conscientiousness - is related to transformational leadership behaviours (Colbert, Barrick \& Bradley, 2014; Deinert, Homan, Boer, \& Gutermann, 2015; Ensari, Riggio, Christian, \& Carslaw, 2011).

\section{The CEB Corporate Leadership Model}

The conceptual framework for the research is provided by the CEB Corporate Leadership Model (Bartram, 2005). The CEB Corporate Leadership Model (Bartram \& Inceoglu, 2011) originates from the generic model of the world of work described in Bartram, Robertson and Callinan (2002) and Kurz and Bartram (2002). It combines the widely acknowledged transactional and transformational themes into four main leadership functions, each emphasizing distinctive types of behaviour that are described by eight broad competency factors as illustrated in Annexure1 ("Great eight": Bartram, 2005). These factors configure the most general level of a three tier hierarchical competency framework. This framework has 112 components (first tier) which defines the relationships between these 
components, their mapping onto a set of 20 broader competency dimensions (the second tier) which in turn load onto eight general competency factors (third tier) describing the domain of desirable behaviours at work (refer Annexure 1). Research has provided evidence that these eight factors not only provide a comprehensive description of work behaviours, but they also provide a structure that relates well to the 'predictor domain'. While management and leadership are conceptually different they are found side by side in practice (Bartram, 2015). It is for that reason that both are incorporated in the CEB Corporate Leadership Model. Outline definitions of the Great Eight are presented in Annexure 1 and their mapping to the leadership functions in Annexure 2.

Annexure 1 includes information on the relationships between the competency factors and underlying personality, ability and motivation factors. Measures that are based on individual dispositions, like personality, that are directly related to and can be expressed by way of competencies, are referred to as measures of competency potential. Thus, one can measure an individual's potential for developing Creating and Conceptualising competencies through levels of general mental ability and some personality attributes (like the 'data rational' scale on the OPQ32r). However, it is important to note that actual competencies are best measured through the appraisals of others who are familiar with the person and their work (e.g., through 360 degree assessments). The Great Eight Factors as illustrated in Annexure 1, provide a sound foundation for defining pairs of dimensions, as outlined above. For each one of the leadership functions, a person can be classified in terms of their score (high or low) on each of the two competency factors that define the function. A summary grid which provides a complete picture of the four main transformational / transactional types is provided by aggregating measures across all four functions. It is important to note that the terms 'transactional' and 'transformational' focus on the behaviours that deliver to agreed goals (i.e. transaction) as opposed to those behaviours that drive change (i.e. transformation) (Bartram, 2015). This offers an accurate assessment of the individual leader's overall approach to leadership (SHL, 2011).

The CEB Corporate Leadership Model merges 'transactional' and 'transformational' themes into the following four main functions that describe the leadership process viz Developing the vision (The strategy domain); Sharing the Goals (The communication domain); Gaining support (The people domain) and Delivering success (The operational domain). As illustrated in Annexure 2, the Great Eight competency factors of the CEB Competency Framework (Bartram, 2005; Kurz \& Bartram, 2002) combine in pairs to provide coverage of these four functions. For each function, one competency factor provides a transformational or leadership focus and the other a transactional or management focus.

Using the above Great Eight factor model, clear links have been established between measures of competency potential based on personality scales from the OPQ32r and ratings from line managers of competencies (Bartram, 2005). Research by Judge et al. (2002) has not only provided evidence of the significance of the relationship between personality traits and leadership as described above, but also demonstrated how the pattern of relationships is subject to context. The two main variables that are used to make any assessment of leadership risk and to determine the appropriate leadership focus (i.e., transactional vs. transformational) are the speed with which change is required and the degree of contextual uncertainty. High pressure for change and contextual uncertainty increase the value of transformational behaviours. Although both good management and leadership are important, unlike management, leadership is a high-risk activity. Lack of effective management will have some negative consequences, but in many cases, the people being managed will keep on working and contributing to the organisation in a positive manner. However, if a leader embarks on the wrong strategic direction, or fails to have the necessary impact in order to achieve a change in strategic direction, the consequences can be devastating for the organisation as a whole (Bartram \& Inceoglu, 2011).

\section{RESEARCH APPROACH}

\section{Research Design}

Data were collected from a group of managers $(\mathrm{N}=124)$ employed at a university of technology using the OPQ32r as part of the Orientation Programme for new deans and Heads of Departments (HODs) and other leadership development programmes between the time period from 2012-2014. Their OPQ32r scores were used to generate a Leadership Report for each individual. The data of managers who have left the employment of the university has been 
excluded from the study. The data of 111 managers were included in the study of whom 55 (49.5\%) were African, 7 Indian (6.3\%), $45(40.5 \%)$ White, and $4(3.6 \%)$ did not indicate which population group they belong to. Their ages ranged between 31 and 62 , with a mean age of 45.72 years $(\mathrm{SD}=7.57)$. There were 46 women $(41.4 \%)$ and 65 men $(58.6 \%)$ in the sample. The majority $(94.6 \%)$ reported to have a post-graduate education level. A total of $108(97.29)$ are managers within the academic environment (Deans, Associate-Deans and HODs) and only 3 were from the support environment (Directors).

\section{Measuring Instrument}

The personality measure used in the present study, the OPQ32r, was developed based on the trait theory personality. The OPQ32r is an occupational model of personality, which describes 32 factors or dimensions of people's preferred style of behaviour at work (SHL, 2013). The OPQ32r is an item response theory (IRT)-scored forced-choice version of OPQ32 that measures similar constructs as its predecessors the OPQ32n and OPQ32i. The OPQ32r however has superior resistance to response bias and score distortion (SHL, 2013). The use of the forced choice format therefore is recommended in contexts where culture specific and uniform response biases needs to be eliminated (Joubert, Inceoglu, Bartram, Dowdeswell \& Lin, 2015).

Several studies support the validity of the OPQ32r both locally and internationally. Several South African studies, for instance, support both the criterion-related and construct validity of the OPQ32r (Bartram, Warr \& Brown, as cited in SHL, 2013). The OPQ32r shows a clear pattern of relationship with criterion measures. A concurrent validity study $(\mathrm{N}=853)$ was conducted internationally across Asia Pacific, North, Central and South America, and Europe using the OPQ32 $r$ as a predictor of performance in terms of managerial competencies. The median correlation of composite personality predictors was 0.32 for the OPQ32r. Best validities for OPQ32 predictions reach as high as 0.30 (short IRT-scored) for colleagues, 0.27 (short IRT-scored) for direct reports, and 0.29 (short IRT-scored) for managers (SHL, 2009).

Joubert et al. (2015) reported South African composite reliabilities on the OPQ32r. The reliabilities were on a par with reliabilities found in international studies and ranged from 0.67 to 0.92 with a median reliability of 0.83 . In an earlier study of bias $(\mathrm{N}=13523)$, no practically significant differences were found between gender and cultural groups in South Africa (Joubert \& Venter, 2013).

A more detailed description of the psychometric properties of this measure and how it was developed can be found in the OPQ32r Technical Manual (SHL, 2013).

The questionnaires were scored by CEB South Africa and the Leadership Report was generated. The Leadership Report provides a detailed understanding of the individual manager's preferred style and competency potential across the four leadership functions described before.

\section{Ethical Aspects}

Permission to conduct the research was obtained from the managers involved and all participants signed an informed consent form in which they consented to the research as well as publication of the results. The test administrator assured the participants that their responses would be dealt with extreme confidentiality and that their anonymity would be safeguarded at all times. For purposes of confidentiality, all recognisable data have been carefully disguised or omitted. Permission to publish the research was obtained from the ethics committee of the university.

\section{DATA ANALYSIS AND RESULTS}

\section{Leadership Potential Summary}

Descriptive statistics for the participants' average sten scores (ranging between 1 and 10) on Transformational / Transactional focus as well as the Great Eight Factors are given in Table 1. The sten scores reflect the mean scores of the participants compared to the South African Managerial \& Professional Norm group. The sten scores of lower than 
6 for seven of the Great Eight Factors, indicate that participants demonstrate either average (between 5 and 6 ) or low average (4) competency potential in these 7 factors as illustrated in Table 1. The participants scored in the low average category for Enterprising \& Performing (4.44), Interacting \& Presenting (4.67), Organising \& Executing (4.95), and Leading \& Deciding (4.99). Average sten scores was obtained for Adapting \& Coping (5.56), Analysing \& Interpreting (5.74) and Creating \& Conceptualising (5.85). The highest competency potential for the group was in the Supporting $\&$ Co-operating with an average sten score of 6.20. The average sten score for the aggregated potential across the four functions of leadership is 5.53 for Transactional and 4.89 for Transformational.

Table 1. Descriptive Statistics of the group summary on the Great 8 Factors and overall Transformation vs. Transactional focus

\begin{tabular}{l|l|c|c|c|c|c}
\hline & \multicolumn{1}{|c|}{ Great 8 Factor Name } & N & Minimum & Maximum & Mean & Std. Deviation \\
\hline Great8 Factor 1 & Leading \& Deciding & 111 & 1 & 9 & 4.99 & 1.64 \\
\hline Great8 Factor 2 & Supporting \& Co-operating & 111 & 2 & 10 & 6.20 & 1.79 \\
\hline Great8 Factor 3 & Interacting \& Presenting & 111 & 1 & 9 & 4.67 & 1.79 \\
\hline Great8 Factor 4 & Analysing \& Interpreting & 111 & 1 & 10 & 5.74 & 1.97 \\
\hline Great8 Factor 5 & Creating \& Conceptualising & 111 & 1 & 10 & 5.85 & 2.09 \\
\hline Great8 Factor 6 & Organising \& Executing & 111 & 1 & 9 & 4.95 & 1.76 \\
\hline Great8Factor 7 & Adapting \& Coping & 111 & 1 & 9 & 5.56 & 2.11 \\
\hline Great8 Factor 8 & Enterprising \& Performing & 111 & 1 & 9 & 4.44 & 1.82 \\
\hline TRANSACTIONAL & Transactional & 111 & 2 & 10 & 5.53 & 1.69 \\
\hline TRANSFORMATIONAL & Transformational & 111 & 1 & 9 & 4.89 & 1.76 \\
\hline
\end{tabular}

Figure 1. Competency potential group summary for Management vs. Leadership Focus

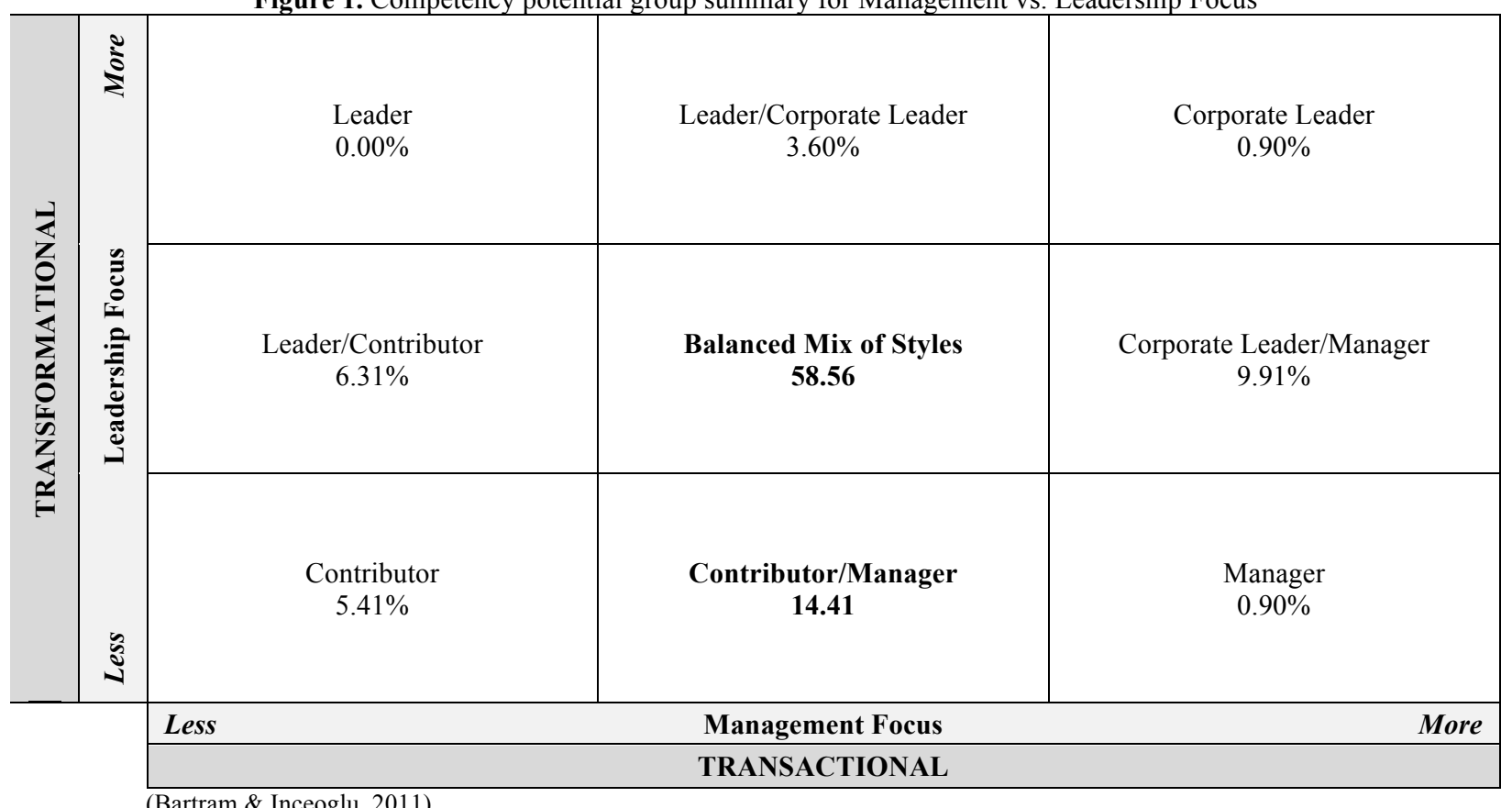

With regard to the aggregated four leadership functions it can be seen in Figure 1 that the majority $(58.56 \%)$ of the participants have a Balanced Mix of Styles between a transformational and transactional focus. This implies that they are likely to adapt their approach to leadership depending on the context and the challenges they are faced with. These leaders are also suitable for roles where they are responsible for ensuring operation efficiency and where they can support others through change. However, leaders with a balanced mix of styles may find it difficult to deal with high performance expectations and pressure for change (OPQ Leadership Report). Only $0.9 \%$ of the participants demonstrated strong competency potential for Corporate Leader and $0 \%$ for Leader. Furthermore, with the regard to 
the overall transactional focus only $0.9 \%$ of the participants have strong competency potential for Manager, with $14.41 \%$ having a Balanced Mix of Styles between Manager/Contributor, and 5.41\% Contributors. From these results it is evident that strong competency potential for both management and leadership might be lacking amongst these managers. This is a cause for concern for as stated by Black (2015), a combination of strong management and leadership competencies is needed in order to successfully address the challenges in the sector and the role of $\mathrm{HE}$ leaders as agents of change to effect institutional transformation has become increasingly important. This pattern was demonstrated across all four of the leadership functions.

\section{Understanding Combinations of Behaviours}

As described earlier, the Great Eight factors provide a basis for defining pairs of dimensions. For each of the four leadership functions, an individual can be classified in terms of how they score on each of the two competency factors that define that leadership function. A nine box model (see Figures 2-5) for each function contains illustrative names to indicate how this can be used for classifying people in terms of their actual leadership behaviours as well as their leadership potential.

Developing the Vision: The Strategy Domain

Figure 2. Competency potential group summary for Function 1: Developing the Vision

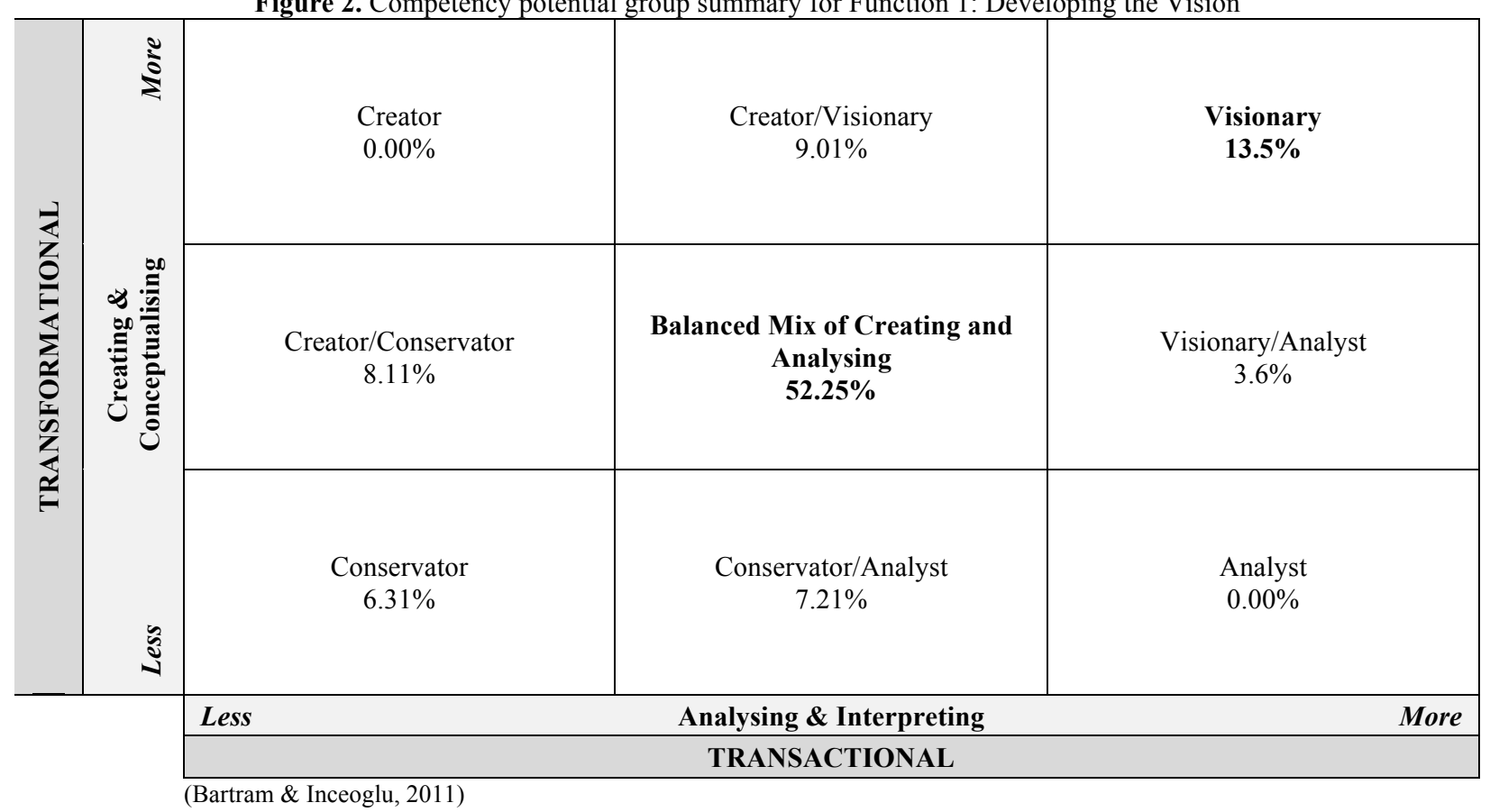

For the function Develop a Vision, $13.51 \%$ fall within the Visionary competency potential category, $6.31 \%$ in the Conservator category, with $0 \%$ in both the Creator and Analyst category. The following mixed styles can be observed: Conservator/Analyst (7.21\%), Creator/Conservator (8.11\%), Creator/Visionary (9.01\%) and Visionary/Analyst $(3.60 \%)$. Thus, for this function it seems that strong transformational competency regarding visionary leadership might be lacking. Furthermore, strong competency potential for both a transactional as well as transformational focus is lacking with $0 \%$ of the participants falling within the categories of Creator and Analyst. This finding is concerning since Drew (2010) found that the most significant challenges in higher education revolve around the need for creativity and strategic leadership. Not only do leaders need to generate creative solutions to meet the challenges in the HE sector (Black, 2015), but also be able to apply critical thinking to get to the heart of complex problems (SHL, 2011). The potential risks involved in these findings include that the vision might be based on an flawed analysis of the 
current situation or that the vision represents an ineffective solution for the problem. Another risk factor is that the change is not recognised throughout the organisation or the sense of urgency is underestimated (Bartram \& Inceoglu, 2011).

Sharing the Goals: The Communication Domain

Figure 3. Competency potential group summary for Function 2 - Sharing the Goals

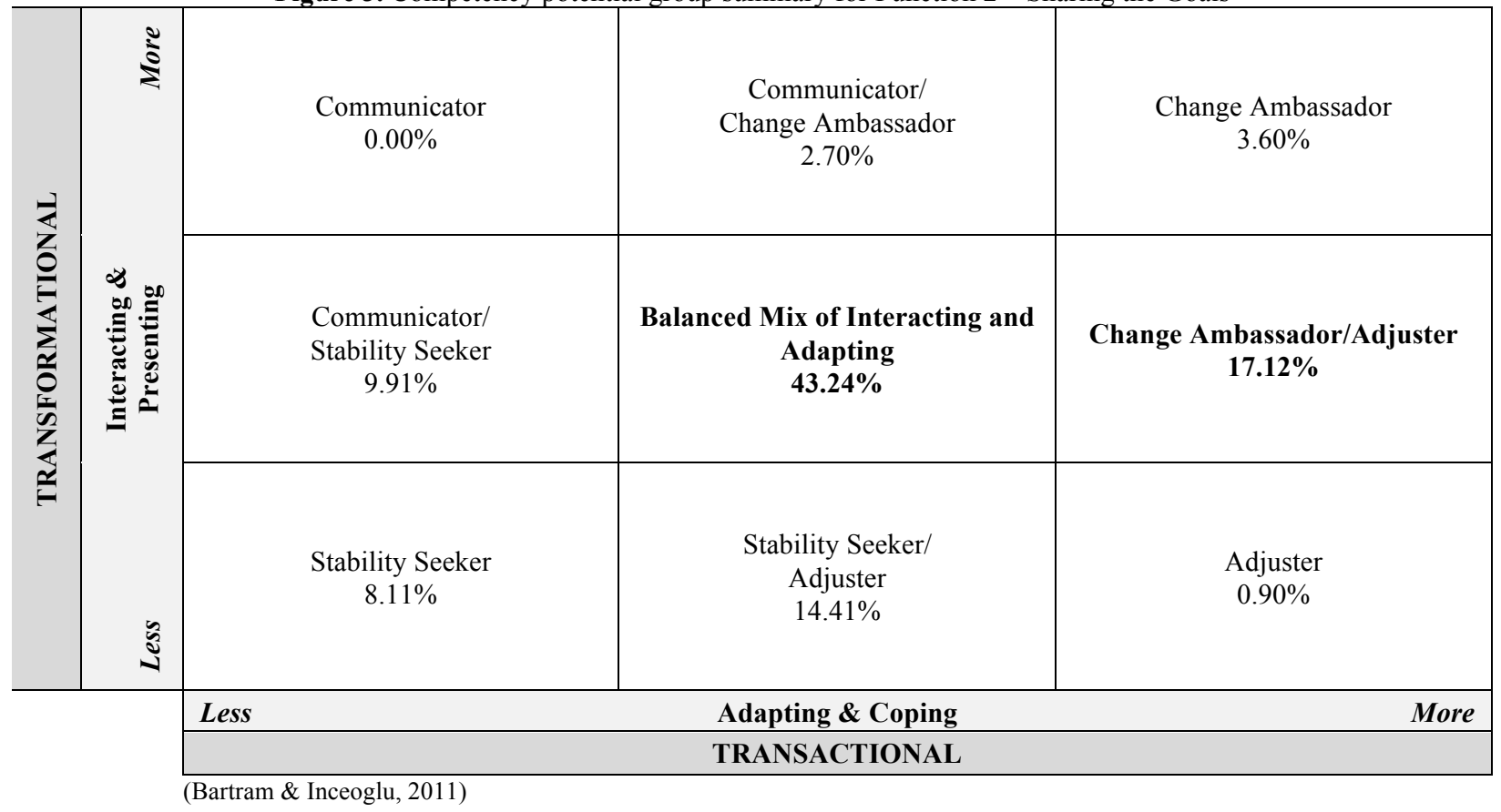

The second function, Sharing the Goals, seems to demonstrate a similar pattern with $43.2 \%$ of participants demonstrating a preference for a Balanced Mix of Interacting and Adapting. These leaders function at their best in contexts where there is only moderate pressurise and might it challenging to operate in high pressure environments where they are being challenged directly (OPQ Leadership Report). Competency potential for the category of Communicator is $0 \%$, Change Ambassador is 3.60\%, Stability Seeker is $8.11 \%$ and $0.90 \%$ for Adjustor. This is a cause for concern because as stated by Northouse (2010) apart from the importance of having a vision, leaders in HE need the ability to communicate goals and align people with specific tasks. It seems as if the majority of these managers might lack the potential to not only to convincingly communicate the new vision and goals but also to personally adapt and to cope effectively with the increased pressure as a result of the change. As stated by Drew (2010) sound interpersonal engagement, specifically relating to change leadership capability is critical to meet the key challenges leaders in higher education are faced with. Furthermore, this finding indicates a possible risk that the significance of the new goals for individuals and the impact thereof on their work is not communicated (Bartram \& Inceoglu, 2011). 


\section{Gaining Support: The People Domain}

Figure 4. Competency potential group summary for Function 3-Gaining Support

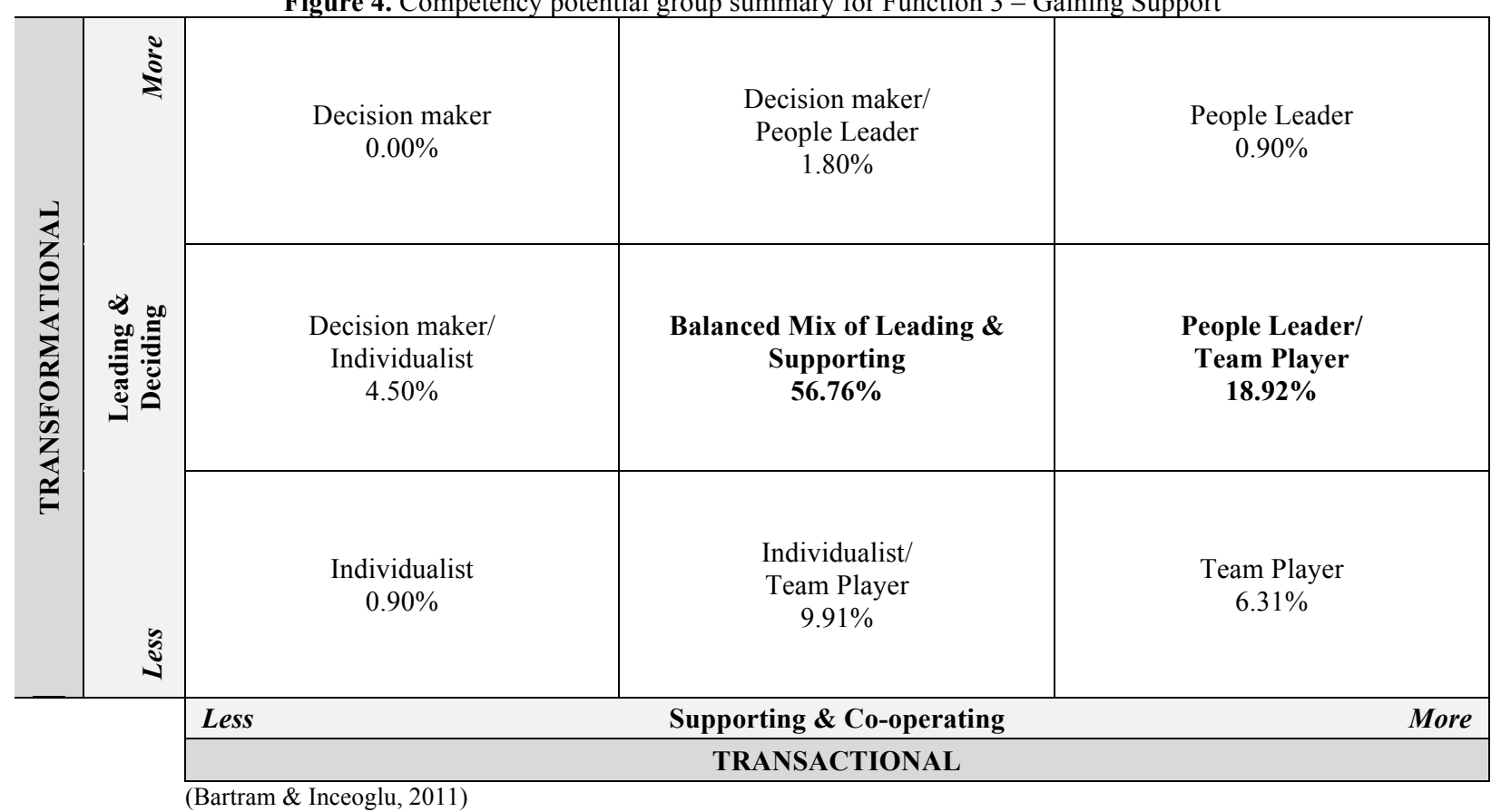

Gaining Support is the third leadership pattern which also illustrates that the majority of the participants (56.76\%) once again prefer a Balanced Mix of Leading and Supporting. These leaders typically take on a flexible approach when supporting and leading others. However, they might find it challenging in roles where tough decisions need to be taken (OPQ Leadership Report). Strong transformational competency potential is lacking with only $0.90 \%$ falling within the People Leader category and $0 \%$ Decision makers. This finding is consistent with research by Ngcamu (2015) who highlighted the unwillingness of leaders to make tough decisions as a factor that impedes transformation. With regard to a transactional focus only $6.31 \%$ of the participants have strong competency potential in the category Team Player and $9.91 \%$ demonstrating a mix between Individualist/Team Player. A mix between a transformational and transactional focus can be observed with $18.92 \%$ with the participants who scored within the People leader/Team Player category. This once raises a concern regarding the participants' potential to be able to motivate and empower others to implement the actions needed to execute the strategy. Fullan and Scott $(2009$, p. 116) indicate that a human dimension forms part of all key challenges of academic leadership; it is therefore important for leaders in HE to excellent interpersonal skills. Therefore, these leaders' ability to provide support through listening, communicating and consulting and dealing with the difficulties associated with large scale change and transformation might be in question. The possible leadership risks involved in these findings are that decisions that are needed to implement the strategy and drive the change process are not taken. This could hamper the transformation agenda in HE since effective and decisive leadership is a key element for meaningful transformation in HEIs (Ngcamu, 2015). Furthermore, the risk exist that line management will not be adequately involved in implementation and/or their methods for dealing with resistance to change are ineffective (Bartram \& Inceoglu, 2011). 


\section{Delivering Success: The Operational Domain}

Figure 5. Competency potential group summary for Function 4 - Delivering Success

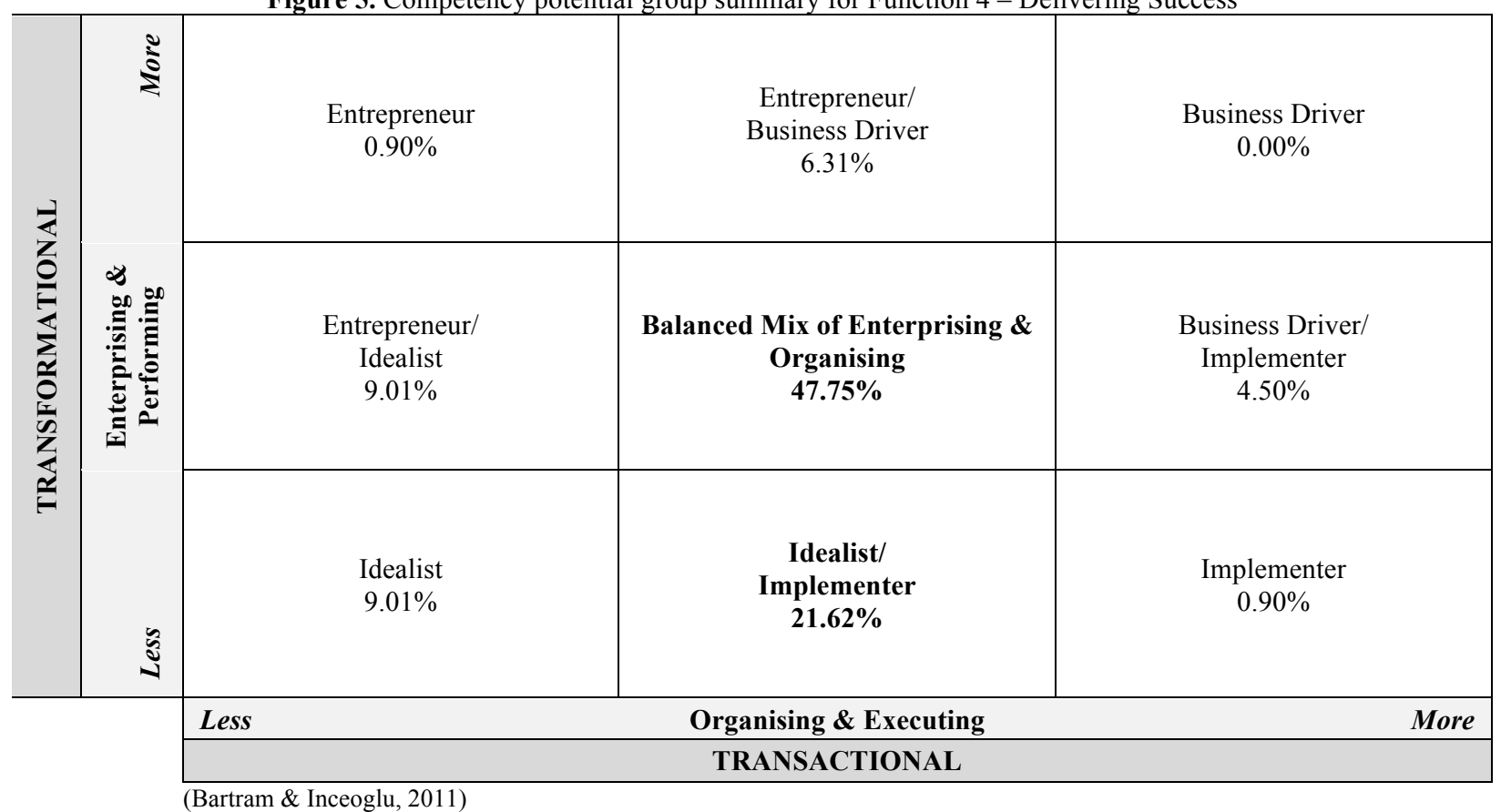

As mentioned before, the fourth leadership function - Delivering Success - is the function that most visibly require a fine balance between management and leadership skills. As illustrated in Figure 5 it is evident the both strong management competency potential as well as strong leadership competency potential is lacking with $47.75 \%$ of participants preferring a Balanced Mix of Enterprising \& Organising. These individuals derive satisfaction by approaching tasks in a steady and consistent manner and are typically less driven by the need for achievement or by commercial considerations. As a result they may fail to take advantage of potential business opportunities (OPQ Leadership Report). Both strong Entrepreneur as well as Implementer potential is lacking, with only $0.90 \%$ of participants demonstrating high competency potential in these two categories. This finding raises the potential leadership risk that operations are not followed through up to completion. This will result in the change process being terminated before the change has become consolidated and entrenched within new organisational norms and values. Furthermore, potential commercial opportunities might be overlooked in the implementation of the strategy, (Bartram \& Inceoglu, 2011). As mentioned before, universities are becoming more business-like and are forced to implement a range of income-generating ventures which has put them in a high-risk position not usually associated with universities (Fullun \& Scott, 2009). The South African Government is also expecting from HEIs to transform to business models (Loomes, 2014). As a result it is crucial that universities be steered by leaders who not only have foresight, but who are also capable of scanning the environment for commercial opportunities and of acting promptly and wisely (Sirat, Ahmad \& Azman, 2012).

\section{DISCUSSION}

The review of the literature highlighted the fact that the highly politicized and regulated HEIs in South Africa are faced with major transformation challenges that require exceptional leadership (Mouton, Louw \& Strydom, 2013; Ngcamu, 2015; Van Ameijde, Nelson, Billsberry \& Meurs, 2009). Furthermore, various authors indicated that transformational leadership is a highly appropriate style of leadership for the HE sector. This study set out to investigate whether HE institutions have the transformational leadership potential to drive change and transformation. 
The findings presented here need to be interpreted with caution. The measures of competency used in this study focus on potential and are based on self-report. They are not independent measures of actual work performance. In other words, they indicate the degree to which individuals will find it 'easy' or 'natural' to demonstrate the appropriate leadership behaviours. However, meta-analysis research by Bartram (2005), provided evidence that these self-reported potential competencies correlate well with line manager ratings of performance in these areas. Nonetheless, 'potential' does directly determine behaviour for most competencies, since it sets the limitations within which the relevant behaviours can develop. Leadership behaviour is a result of potential, constraints, and of motivational and contextual demands. Hence, it is quite possible that someone with low potential in one area will demonstrate relatively strong levels of performance in that same area due to contextual factors, development interventions as well as their strength of motivation (Bartram, 2015).

Despite the limitations of the study the findings of this study showed that the majority of respondents had a balanced mix of styles between a transformational and transactional focus. This is indicative of an overall lack of both strong leadership (transformational) as well as management (transactional) potential amongst this group of managers. This finding is cause for concern, since as stated by Basham (2012) a blend of both strong transformational and transactional leadership is recommended. The importance of transformational leadership is emphasised by Sirat, Ahmad and Azman (2012) who states that 'positions of university leadership need to be filled by leaders who are characteristically transformational and forward-looking' (p. 512). The results of this study is in line criticism mentioned before that managers in HEIs lack the capacity to effectively manage change and lead transformation (Mabelebele, 2013; Ngcamu, 2015). Furthermore, it also contradicts the finding by Vinger and Cilliers (2006) that the level of transformational leadership amongst leaders in HEIs in South Africa is relatively high. Without exception, the majority of respondents demonstrated a preference for a Balanced mix of styles across all four the leadership functions, with only a few of the respondents demonstrating strong competency potential for either a strong transactional or transformational focus or approach to leadership. As mentioned before, uncertainty and the pressure for change are two of the major factors that HEIs have to respond to which would imply a high reliance on transformational leadership competencies. This lack of a strong transformational focus amongst managers, might impact negatively on team performance and trust in leadership (Chou, Lin, Chang \& Chuang, 2013) as well as the emotional commitment of employees to the university (Barling et al. 2000).

As mentioned in the previous section, these findings pose serious potential leadership risks across the four leadership functions. Although both good management and leadership are important, leadership, unlike management is a highrisk activity. If a leader embarks on the wrong strategic direction, or fails to create the momentum for a change in direction, the results can be devastating for the organisation as a whole (Bartram \& Inceoglu, 2011). As indicated by Chipunza and Gwarinda (2010) when the leader does not provide clear strategic direction as well as empower followers it will lead to dissatisfaction with the whole process, even if the transformation process is declared a success.

To summarise, the results of this study indicate a lack of transformational leadership potential amongst managers. Consequently, strong transformational leadership behaviours will not be 'easy' or 'natural' for these leaders to demonstrate. These results have important implications for HEIs and from a practical standpoint serve to inform two essential organisational initiatives: leadership selection and leadership development. Most importantly, as the selection, succession planning and promotion decisions are made for a university's leaders, every effort should be made to select individuals with the potential to demonstrate high levels of transformational leadership.

The leadership crisis in South Africa's public universities necessitates that a total reform has to be instituted, not only with regard to the selection of university leaders, but as stated by Black (2015), institutions should reconsider how they develop their leadership talent and what constitute appropriate leadership behaviour. This is confirmed in a study by Seale and Cross (2016) which revealed that the South African higher education system 'lacks an adequate, appropriate response to leadership development for senior managers' (p.1515). Although it not possible to change the natural competency potential or personality dispositions of managers, Bass (1998) has reported that it is indeed possible to teach managers the precepts of transactional and transformational leadership. This is confirmed by various studies that transformational leadership can be improved by training managers to employ transformational leadership behaviours to impact organizational outcomes (Abrell, Rowold, Weibler \& Moenninghoff, 2011; Brown \& May, 2012; Dvir, Eden, Avolio \& Shamir, 2002). In this regard, many organisations have adopted a personality-based approach 
towards leadership development (McCormick \& Burch, 2008). These programmes typically use personality assessments (e.g., the OPQ) to bring about positive behavioural change since it increase leaders' self-awareness regarding their weaknesses and strengths. This approach is in line with a recent study by Ngcamu (2016) which revealed that university leaders do not have insight into their personal weaknesses. The notion that it is possible for HEIs to train their managers to utilize transformational leadership behaviours to impact organizational outcomes along with coaching and other leadership experiences that subject leaders to situations that will require from them to demonstrate transformational leadership will help build a pipeline of leaders able to drive the transformation agenda in HE (Judge \& Piccolo, 2004; Wang, Oh, Courtright \& Colbert, 2011). These attributes are not only important for senior leaders but for all levels of the university management. Both the speed with which transformation is required as well as current degree of contextual uncertainty are both key factors which increase the value of transformational behaviours within HEIs (Seale \& Cross, 2016).

\section{CONCLUSION}

This study makes a significant contribution, by identifying the current leadership potential, in an area that is crucial to the successful transformation of the HE sector. In line with the appeal made by Seale and Cross (2016) the results necessitate a strategic approach to leadership development with development interventions that respond to both individual and institutional needs. To address the leadership realities HEIs are faced with, it is imperative that contextually adaptive people who can lead transformation are developed in order to foster reformed and transformed HE institutions.

Academic leaders will continue to need, first and foremost, superior scholarship competencies, but based on the abovementioned findings, such competencies will need to be augmented with the competencies associated with effective transformational leadership. These should include, abilities across the four leadership functions to provide a complete view of leadership which takes cognisance of the complexities of transformation in the South African higher education arena.

\section{LIMITATIONS OF THE STUDY AND FUTURE DIRECTION OF STUDY}

The scope of the study is limited because only one institution (a university of technology) was involved. Hence the findings of this study cannot be generalised to all HEIs in South Africa. Other researchers are encouraged to replicate this study in other HEIs in South Africa as a way to develop comprehensive national remedial plans where commonalities exist. Future studies can extend and add greater depth by adding performance data to assess transformational leadership behaviours.

\section{ACKNOWLEDGEMENTS}

The authors would like to express their appreciation to the anonymous referees, whose suggestions have improved the quality of this paper. A special gratitude to Tina Joubert, Senior Research Consultant at CEB Talent Measurement Solutions for her assistance with the statistical analysis and interpretation of the OPQ data. The views expressed in this paper are solely those of the authors and not necessarily those of the organisation that they are associated with.

\section{AUTHOR BIOGRAPHIES}

Dr. Tessie Herbst is a registered psychologist and also accredited as a master HR professional at the South African Board for People Practices (SABPP). She also has a master of theology with specialization in counseling. Being in the field of leadership development for more than 20 years, she now heads the leadership and management development function at the Tshwane University of Technology. She is responsible for the talent management of senior and middle managers within the university. She specializes in emotional intelligence and leadership psychology. She is also a licensed associate of the 6seconds international emotional intelligence network and a certified trained practitioner of the MSCEIT (an ability measure of emotional intelligence) as well as the Bar-On EQ-i. 
Herbst is the author of the book The Dark side of Leadership and also published various peer reviewed articles and chapters in books in the field of leadership development. She is often invited as keynote speaker and conducted seminars and presented papers at several national and international conferences.

Professor Ajay K Garg has an eclectic combination of varied industry experience, teaching, research publications and academic supervision. He has Masters Qualifications from highly prestigious universities in India: one in engineering from Indian School of Mines and the other in management from Delhi University. His doctorate is in strategic management from South Africa.

On the academic front, he is currently based at TUT Business School, Pretoria and teaches Research Methodology to MBA students and has successfully supervised more than $50 \mathrm{MBA}$ and Doctoral students. His publications are spread around Asia, Africa, Europe, North America, New Zealand and East Europe, covering IBSS, ISI and ABDC (Australian Business Deans Council) indexed journals. Also, he is a Rated Researcher by National Research Foundation (NRF) of South Africa.

Professor Garg acts as a liaison to provide technical and research assistance on Mineral Certification in Rwanda, Democratic Republic of Congo, Uganda, Burundi, Uganda and Tanzania with other interested parties. Previously, he worked for the government of Botswana to help set up Kimberley process certification scheme in the country. Prof. Garg can be contacted at gargak@tut.ac.za; akg20055@yahoo.co.in. (Corresponding author)

\section{REFERENCES}

Abrell, C., Rowold, J., Weibler, J. \& Moenninghoff, M. (2011). Evaluation of a long-term transformational leadership development program. Zeitschrift für Personalforschung / German Journal of Research in Human Resource Management, 25, H. 3, 205-224.

Anderson, D. \& Johnson, R. (2006). Ideas of leadership underpinning proposals to the Carrick Institute: A review of proposals from the 'Leadership for Excellence in Teaching and Learning Program'. Carrick Institute Leadership Forum. Sydney, Australia.

Barling, J. F., Slater, F. J. \& Kelloway, E. K. (2000). Transformational leadership and emotional intelligence: an exploratory study. Leadership and Organization Development Journal, 21(2), 157-161.

Barroso Castro, C., Villegas Periñan, M. M., \& Casillas Bueno, J. C. (2008). Transformational leadership and followers' attitudes: the mediating role of psychological empowerment. The International Journal of Human Resource Management, 19(10), 1842-1863.

Bartram, D. (2005). The Great 8 competencies: A criterion-centric approach to validation. Journal of Applied Psychology, 90 , 1185-1203.

Bartram, D. (2009). Leadership competencies: Differences in patterns of potential across eleven European countries as a function of gender and managerial experience. Advances in Global Leadership, 5, 35-64. doi.org/10.1108/S15351203(2009)0000005006.

Bartram, D. \& Inceoglu, I. (2011). The SHL Corporate Leadership Model (2 ${ }^{\text {nd }}$ Ed.). SHL White paper, Thames Ditton, UK: SHL Group Ltd.

Bartram, D. (2015). Leadership competencies: Differences in patterns of potential across eleven European countries as a function of gender and managerial experience. Advances in Global Leadership, 5, 35-64. Published online: 09 Mar 2015; 35-64. http://dx.doi.org/10.1108/S1535-1203(2009)0000005006.

Bartram, D., Robertson, I. T. \& Callinan, M. (2002). Introduction: A framework for examining organizational effectiveness. In I. Robertson, M. Callinan \& D. Bartram (Eds), Organizational effectiveness: The role of psychology (pp. 1-12). London: Wiley.

Basham, L.M. (2012). Transformational and transactional leaders in higher education. S.A.M. Advanced Management Journal, $77(2), 15-23$.

Bass, B. M. (1985). Leadership and performance beyond expectations. New York: Free Press.

Bass, B. M. (1978). Bass and Stogdill's Handbook of Leadership: Theory, Research, and Managerial Applications (3rd edn.). New York: Free Press.

Bass, B.M. (1998). Transformational leadership: Industry, military and educational impact. Mahwah, NJ: Erlbaum.

Benson, M. J. \& Campbell, J. P. (2007). To be, or not to be, linear: An expanded representation of personality and its relationship to leadership performance. International Journal of Selection and Assessment, 15(2), 232-249.

Black, S. (2015). Qualities of effective leadership in higher education. Open Journal of Leadership, 4, 54-66. doi.org/10.4236/oj1.2015.42006. 
Bolden, R., Petrov, G. \& Gosling, J. (2008). Developing collective leadership in higher education. In H. Goreham, H. (Ed.), Research and Development Series. London: Leadership Foundation for Higher Education.

Bono, J. E. \& Judge, T. A. (2004). Personality and Transformational and Transactional Leadership: A Meta-Analysis. Journal of Applied Psychology, 89, 5, 901-910.

Bendermacher, G. W. G., oude Egbrink, M. G. A.,. Wolfhagen, I. H. A. P. \& Dolmans, D. H. J. M. (2016). Unravelling quality culture in higher education: a realist review. Higher Education, doi: 10.1007/s10734-015-9979-2.

Brown, W. \& May. D. (2012). Organizational change and development: The efficacy of transformational leadership training. Journal of Management Development, 31(6), 520-536. doi.org/10.1108/02621711211230830

Burns, J. M. (1978). Leadership. New York. Harper \& Row.

Bush, T. (2007). Educational leadership and management: Theory, policy, and practice. South African Journal of Education, 27(3), 391-406.

Chipunza, C. \& Gwarinda, S. A. (2010). Transformational leadership in merging higher education institutions: A case study. $S A$ Journal of Human Resource Management/SA Tydskrif vir Menslikehulpbronbestuur, 8(1), doi: 10.4102/sajhrm.v8i1.195.

Chou, Huey-Wen., Lin, Yu-Hsun., Chang, Hsiu-Hua. \& Chuang, Wen-Wei. (2013). Transformational leadership and team performance: The mediating roles of cognitive trust and collective efficacy. SAGE Open, July-September, 1-10, doi:10.1177/2158244013497027.

Colbert, A. E., Barrick, M. R. \& Bradley, B.H. (2014). Personality and leadership composition in top management teams: Implications for organizational effectiveness. Personnel Psychology, 67(2), 351-387.

Colbert, A. E., Judge, T. A., Choi, D. \& Wang, G. (2012). Assessing the trait theory of leadership using self and observer ratings of personality: The mediating role of contributions to group success. The Leadership Quarterly, 23, 670-685

Council on Higher Education (CHE) (2016). South African Higher Education Reviewed: Two Decades of Democracy. CHE: Pretoria.

Deinert, A., Homan, A. C., Boer, D. \& Gutermann, D. (2015). Transformational leadership sub-dimensions and their link to leaders' personality and performance. The Leadership Quarterly, 26(6):1095-1120.

Do, M. H. \& Minbashian, A. (2014). A meta-analytic examination of the effects of the agentic and affiliative aspects of extraversion on leadership outcomes. The Leadership Quarterly, 25, 1040 - 1053.

Drew, G. (2010). Issues and challenges in higher education: Engaging for change. The Australian Educational Researcher, 37(3), 57-76.

Dvir, T., Eden, D., Avolio, B. J. and Shamir, B. (2002). Impact of transformational leadership on follower development and performance: a field experiment. Academy of Management Journal, 45(4), 735-744.

Ensari, N., Riggio, R. E., Christian, J., \& Carslaw, G. (2011). Who emerges as a leader? Meta-analyses of individual differences as predictors of leadership emergence. Personality and Individual Differences, 51(4), 532-536. http://dx.doi.org/10.1016/j.paid.2011.05.017.

Evans, J. R. (2011). Quality management, organization and strategy. (6 $6^{\text {th }}$ edn.). Cincinnati: South Western.

Fullan, M., \& Scott, G. (2009). Turn and Leadership for Higher Education. John Wiley \& Sons: San Francisco.

Garwe, E. C. (2014). The effect of institutional leadership on quality of higher education provision. Research in Higher Education Journal. 22.

Goffee, R. \& Jones, G. (2009). Clever: Leading Your Smartest, Most Creative People. Boston, MA: Harvard Business Press.

Gumusluoglu, L., \& Ilsev, A. (2009). Transformational leadership, creativity, and organizational innovation. Journal of Business Research, 62(4), 461-473.

Herbst, T.H.H. \& Conradie P.D.P. (2011). Leadership effectiveness in Higher Education:

Managerial self-perceptions versus perceptions of others, South African Journal of Industrial Psychology, 37(1), 1-14.

Hogan, R. (2006). Personality and the Fate of Organizations. Mahwah, NJ: Lawrence Erlbaum Associates.

Hogan, R \& Benson. M. J. (2009). Personality, Leadership, and Globalization: Linking Personality to Global Organizational Effectiveness, In Advances in Global Leadership, 5, 11-34, http://dx.doi.org/10.1108/S1535-1203(2009)0000005005

Hogan, R. \& Judge, T. (2013). Personality and Leadership. In M.G. Rumsey (Ed.), The Oxford handbook of leadership, Oxford University Press: New York.

Howell, J. M., \& Avolio, B. J. (1993). Transformational leadership, transactional leadership, locus of control, and support for innovation: Key predictors of consolidated-business-unit performance. Journal of Applied Psychology, 78(6), 891-902.

Jarvis, P. (2013). Universities and Corporate Universities: The higher learning industry in global society. Routledge: New York.

Joubert, T., \& Venter, N. (2013). Occupational Personality Questionnaire (OPQ). In S. Laher, \& K. Cockcroft (Eds.), Psychological assessment in South Africa: Research and applications (pp. 277-291). Johannesburg, South Africa: Wits University Press.

Joubert, T., Inceoglu, I., Bartram, D., Dowdeswell, K. \& Lin, Y. (2015). A comparison of the psychometric properties of the Forced choice and Likert Scale versions of a personality assessment. International Journal of Selection and Assessment, 23(1). 92-97.

Judge, T. A. \& Bono, J. E. (2000). Five-Factor Model of Personality and Transformational Leadership. Journal of Applied Psychology, 85, 751-765. 
Judge, T. A., Bono, J. E., Ilies, R. \& Gerhardt, M. W. (2002). Personality and leadership: A qualitative and quantitative review. Journal of Applied Psychology, 87, 765-780.

Judge, T. A. \& Piccolo, R. F. (2004). Transformational and transactional leadership: A meta-analytic test of their relative validity. Journal of Applied Psychology, 89, 755-768.

Kark, R., Shamir, B., \& Chen, G. (2003). The two faces of transformational leadership: Empowerment and dependency. Journal of Applied Psychology, 88(2), 246-255.

Korek, S., Felfe, J., \& Zaepernick-Rothe, U. (2010). Transformational leadership and commitment: A multilevel analysis of group-level influences and mediating processes. European Journal of Work and Organizational Psychology, 19(3), 364-387.

Kurz, R. \& Bartram, D. (2002). Competency and individual performance: Modelling the world of work. In I. Robertson, M. Callinan \& D. Bartram (Eds), Organizational Effectiveness: The Role of Psychology (pp. 227-258). London: Wiley.

Lim, J. Y. \& Cromartie, F. (2001). Transformational leadership, organizational culture and organizational effectiveness in sport organizations. The Sport Journal, 4(2), 111-169.

Loomes, S. L. (2014). Recruitment and selection of senior academic leaders in Australian universities. Unpublished thesis, University of Wollongon, Sydney.

Mabelebele, J. (2013). Leading and Managing Higher Education Institutions in South Africa: Some Thoughts. Keynote address delivered at the 2013 Higher education leadership and management (HELM) workshop hosted by HESA; the Airport grand hotel, Boksburg, 13 March 2013.

Macupe, B. (2012). Poor leadership cripples tertiary institutions. Sunday Independent, p 7.

Mader, C., Scott, G. \& Razak, D.A (2013). Effective change management, governance and policy for sustainability transformation in higher education. Management and Policy Journal, 4(3), 264-284.

McCormick, I. \& Burch, St. J. G. (2008). Personality-focused coaching for leadership development. Consulting Psychology Journal: Practice and Research, 60, 3, 267-278.

Martin, E., Trigwell, K., Prosser, M. \& Ramsden, P. (2003). Variation in the experience of leadership of teaching in higher education: Studies in Higher Education, 23(3), 247-259.

Middlehurst, R., Goreham, H. \& Woodfield, S. (2009). Why research leadership in higher education? Exploring contributions from the UK's leadership foundation for higher education. Leadership, 5(3), 311-329.

Middlehurst, R. (2012). Leadership and Management in Higher Education: A Research Perspective. Working Paper No. 2012/47.

Mouton, N., Louw, G. P. \& Strydom, G. L. (2013). Present-day dillemas and challenges of the South African tertiary system. International Business \& Economics Research Journal, 12(3), 285-300.

Ngcamu, B. S. (2015). Leadership and transformation in a South African university. Problems and Perspectives in Management. $13(1), 208-216$.

Ngcamu, B. S. (2016). An exploratory study on the influence of leadership on transformation in a higher education institution: A case of the Durban University of Technology. Published thesis: University of KwaZulu-Natal.

Northouse, P. G. (2010). Leadership: Theory and practice (5th edn.). Thousand Oaks, CA: Sage Publications. OPQ32r Technical Manual version 1.0. (2013). SHL Group Ltd.

Pihie, Z. A. L., Sadeghi, A. \& Elias, H. (2011). Analysis of head of departments leadership styles: Implication for improving research university management practices. Procedia - Social and Behavioral Sciences, 29 (2011) $1081-1090$.

Potgieter, I. L. \& Coetzee, M. (2010). Management competencies in higher education: Perceived job importance in relation to level of training required. SA Journal of Human Resource Management/SA Tydskrif vir Menslikehulpbronbestuur, 8(1), Art. \#306, 10 pages. doi: 10.4102/sajhrm.v8i1.306

Puccio, G.J., Mance, M. \& Murdock, M. C. (2011). Creative leadership. Skills that drive change. Thousand Oaks: Sage.

Rashed, F. \& Daud, K. (2013). Effects of transformational leadership on organisational commitment at university department level. In 2nd International Seminar on Quality and Affordable Education (ISQAE 2013).

Salanova, M., Lorente, L., Chambel, M. J., \& Martínez, I. M. (2011). Linking transformational leadership to nurses' extra-role performance: the mediating role of self-efficacy and work engagement. Journal of Advanced Nursing, 67(10), $2256-66$.

Saucier G, \& Goldberg, L. R. (2003). The structure of personality attributes. In Barrick MR, Ryan AM (Eds.), Personality and work: Reconsidering the role of personality in organizations (pp. 1-29). San Francisco, CA: Jossey-Bass.

Seale, O. \& Cross, M. (2016) Leading and managing in complexity: the case of South African deans. Studies in Higher Education, 41:8, 1514-1532, DOI:10.1080/03075079.2014.988705

Shahmandi, E., Silong, A. D., Ismail, I.A., Samah, B.B.A. and Othman, J. (2011). Competencies, roles and effective academic leadership in a world class university. International Journal of Business Administration, 2(1), 44-53.

SHL (2009). Development of OPQ32r using Item Response Theory. Supplement to OPQ32 Technical Manual. Surrey, UK. SHL Group Ltd.

SHL. (2013). OPQr Technical Manual version 1.0. Thomas Ditton, UK: SHL Group Ltd.

SHL (2011). SHL Leadership Report Technical Manual. SHL Group Ltd.

Sirat, M., Ahmad, A. R. \& Azman, N. (2012). University leadership in crisis: The need for effective leadership positioning in Malaysia. Higher Education Policy, 25, 511-529.

Copyright by author(s); $\underline{\text { CC-BY }}$ 
Van Ameijde, J. D. J., Nelson, P. C., Billsberry, J. \& Van Meurs, N. (2009). Improving leadership in Higher Education Institutions: a distributed perspective. Higher Education, doi:10.1007/s10734-009-9224-y.

Vinger, G. \& Cilliers, F. (2006). Effective transformational leadership behaviours for managing change. SA Journal of Human Resource Management/ SA Tydskrif vir Menslikehulpbronbestuur, 4(2), 1-9.

Wang G., Oh, I. S., Courtright, S. H. \& Colbert, A. E. (2011). Transformational leadership and performance across criteria and levels: A meta-analytic examination of 25 years of research. Group and Organization Management, 36, $223-270$.

Wang, X.-H., \& Howell, J. M. (2012). A multilevel study of transformational leadership, identification, and follower outcomes. The Leadership Quarterly, 23(5), 775-790.

Yukl, G. (1999). An evaluation of conceptual weaknesses in transformational and charismatic leadership theories. The Leadership Quarterly, 10(2), 285-305.

Zulfqar, A., Devos, G., Shahzad, A. H., \& Valcke, M. (2015). Transformational leadership, participative decision making versus self-efficacy, intrinsic motivation and job satisfaction in Pakistan higher education. Annual meeting of the American Educational Research Association. 
ANNEXURE 1: Titles and High Level Definitions of the Great Eight Competencies

\begin{tabular}{|c|c|c|c|}
\hline Factor & Competency Title Domain & Competency Domain Definition & $\begin{array}{l}\text { Hypothesized Big Five, } \\
\text { Motivation an Ability } \\
\text { Relationships }\end{array}$ \\
\hline 1 & Leading \& Deciding & $\begin{array}{l}\text { Takes control and exercises leadership. } \\
\text { Initiates action, gives direction and takes } \\
\text { responsibility }\end{array}$ & $\begin{array}{l}\text { Need for Power and Control, } \\
\text { Extraversion }\end{array}$ \\
\hline 2 & Supporting \& Co-operating & $\begin{array}{l}\text { Supports others and shows respect and positive } \\
\text { regard for them in social situations. Puts people } \\
\text { first, working effectively with individuals and } \\
\text { teams, clients and staff. Behaves consistently } \\
\text { with clear personal values that complement } \\
\text { those of the organization. }\end{array}$ & Agreeableness \\
\hline 3 & Interacting \& Presenting & $\begin{array}{l}\text { Communicates and networks effectively. } \\
\text { Successfully persuades and influences others. } \\
\text { Relates to others in a confident and relaxed } \\
\text { manner. }\end{array}$ & $\begin{array}{l}\text { Extraversion, } \\
\text { General } \\
\text { mental ability }\end{array}$ \\
\hline 4 & Analyzing \& Interpreting & $\begin{array}{l}\text { Shows evidence of clear analytical thinking. } \\
\text { Gets to the heart of complex problems and } \\
\text { issues. Applies own expertise effectively. } \\
\text { Quickly takes on new technology. } \\
\text { Communicates well in writing. }\end{array}$ & $\begin{array}{l}\text { General mental ability, } \\
\text { Openness to experience }\end{array}$ \\
\hline 5 & Creating \& Conceptualizing & $\begin{array}{l}\text { Works well in situations requiring openness to } \\
\text { new ideas and experiences. Seeks out learning } \\
\text { opportunities. Handles situations and problems } \\
\text { with innovation and creativity. Thinks broadly } \\
\text { and strategically. Supports and drives } \\
\text { organizational change. }\end{array}$ & $\begin{array}{l}\text { Openness to experience, } \\
\text { General mental ability }\end{array}$ \\
\hline 6 & Organizing \& Executing & $\begin{array}{l}\text { Plans ahead and works in a systematic and } \\
\text { organized way. Follows directions and } \\
\text { procedures. Focuses on customer satisfaction } \\
\text { and delivers a quality service or product to the } \\
\text { agreed standards. }\end{array}$ & $\begin{array}{l}\text { Conscientiousness General } \\
\text { mental ability }\end{array}$ \\
\hline 7 & Adapting \& Coping & $\begin{array}{l}\text { Adapts and responds well to change. Manages } \\
\text { pressure effectively and copes well with } \\
\text { setbacks. }\end{array}$ & Emotional Stability \\
\hline 8 & Enterprising \& Performing & $\begin{array}{l}\text { Focuses on results and achieving personal work } \\
\text { objectives. Works best when work is related } \\
\text { closely to results and the impact of personal } \\
\text { efforts is obvious. Shows an understanding of } \\
\text { business, commerce and finance. Seeks } \\
\text { opportunities for self-development and career } \\
\text { advancement. }\end{array}$ & $\begin{array}{l}\text { Need for achievement, Negative } \\
\text { agreeableness }\end{array}$ \\
\hline \multicolumn{4}{|c|}{$\begin{array}{l}\text { Source: The titles and definitions in this table are taken from the SHL Universal Competency Framework }{ }^{\mathrm{TM}} \text { Profiler Cards (copyright } \mathbb{C} 2004 \text { by } \\
\text { SHL Group plc, reproduced with permission of the copyright holder). These titles and definitions may be freely used for research purposes subjec } \\
\text { to due acknowledgement of the copyright holder. The final column shows the hypothesized relationships between the Big Five, General Menta } \\
\text { Ability and Motivation for the Great Eight. Where more than one predictor is shown, the second is expected to be of lesser importance than th } \\
\text { first. }\end{array}$} \\
\hline
\end{tabular}


ANNEXURE 2: The CEB Corporate Leadership Model

\begin{tabular}{|c|c|c|c|}
\hline \multirow{2}{*}{$\begin{array}{l}\text { LEADERSHIP } \\
\text { FUNCTIONS }\end{array}$} & \multirow[t]{2}{*}{ Definition } & \multicolumn{2}{|c|}{ COMPETENCIES } \\
\hline & & Transactional & Transformational \\
\hline $\begin{array}{l}\text { 1. Developing the } \\
\text { Vision: Strategy } \\
\text { Domain }\end{array}$ & $\begin{array}{l}\text { This involves the critical analysis of } \\
\text { the current situation, and the } \\
\text { generation of ideas to move forward } \\
\text { (Strategy) }\end{array}$ & $\begin{array}{l}\text { Analysing and Interpreting } \\
\text { Analysing complex } \\
\text { information and applying } \\
\text { expertise }\end{array}$ & $\begin{array}{l}\text { Creating and Conceptualising } \\
\text { Producing innovative ideas } \\
\text { and thinking strategically }\end{array}$ \\
\hline $\begin{array}{l}\text { 2. Sharing the Goals: } \\
\text { The communication } \\
\text { domain }\end{array}$ & $\begin{array}{l}\text { This involves persuasively } \\
\text { communicating the vision to others, } \\
\text { as well as personally adapting to the } \\
\text { changes that the new strategy brings } \\
\text { (Communication) }\end{array}$ & $\begin{array}{l}\text { Interacting and Presenting } \\
\text { Responding and adapting } \\
\text { well to change and } \\
\text { pressure }\end{array}$ & $\begin{array}{l}\text { Adapting and Coping } \\
\text { Communicating with, } \\
\text { persuading and influencing } \\
\text { others }\end{array}$ \\
\hline $\begin{array}{l}\text { 3. Gaining Support: } \\
\text { The people domain }\end{array}$ & $\begin{array}{l}\text { This involves gaining others } \\
\text { people's support by motivating and } \\
\text { empowering them to implement the } \\
\text { actions needed to deliver the } \\
\text { strategy (People) }\end{array}$ & $\begin{array}{l}\text { Supporting and } \\
\text { Cooperating } \\
\text { Supporting others and } \\
\text { working effectively with } \\
\text { people }\end{array}$ & $\begin{array}{l}\text { Leading and Deciding } \\
\text { Initiating action, giving } \\
\text { direction and taking } \\
\text { responsibility }\end{array}$ \\
\hline $\begin{array}{l}\text { 4. Delivering Success: } \\
\text { The operational } \\
\text { domain }\end{array}$ & $\begin{array}{l}\text { This involves using operational } \\
\text { efficiency and commercial acumen } \\
\text { to effectively implement the strategy } \\
\text { (Operations) }\end{array}$ & $\begin{array}{l}\text { Organizing and Executing } \\
\text { Planning, working in an } \\
\text { organised manner and } \\
\text { focusing on delivery }\end{array}$ & $\begin{array}{l}\text { Enterprising and Performing } \\
\text { Focusing on results and on } \\
\text { achieving goals }\end{array}$ \\
\hline
\end{tabular}

Source: The SHL Leadership Report, Technical Manual, 2011 